\title{
Thunbergia impatienoides (Acanthaceae), a new species from Thailand
}

\author{
C. Suwanphakdee ${ }^{1,2}$, S. Vajrodaya ${ }^{1}$
}

Key words

new species

pollen

Thailand

Thunbergia
Abstract Anew species, Thunbergia impatienoides, was discovered from Thailand and is here described. Detailed descriptions including pollen and seed morphologies, distribution, ecology and illustration are provided.

Published on 30 April 2018

\section{INTRODUCTION}

Thunbergia is a large genus of Acanthaceae subfamily Thunbergioideae s.lat. (Brummitt 1989, Takhtajan 1997, Schönenberger \& Endress 1998), consisting of c. 100 species distributed in tropical and subtropical regions of Africa, Madagascar, Asia and Australia (Borg et al. 2008). The members of Thunbergia differ from most other Acanthaceae mainly in their lack of retinacula and cystoliths, their twining habit (a few species are erect), large floral bracts and bracteoles (prophylls), reduced calyx and lack of an endothecium (Lindau 1895, Bremekamp 1953, Schönenberger \& Endress 1998).

The morphological characters of Asian Thunbergia are: Perennial herbaceous or woody climbers, shrubs, rarely erect or trailing herbs without cystoliths. The leaves are always simple and with a petiole, they are opposite, ovate or lanceolate to hastate or sagittate and their margins are entire to lobed to dentate. The flowers are pedicellate, axillary, solitary, paired, up to four arranged in fascicles or with many flowers in racemes with leaf-like bracts. The bracteoles are paired and enclosing the calyx and most or all of the corolla tube, sometimes fused on one side and persistent. The calyx is annular and much shorter than the bracteoles, subentire, undulate or 5-20-toothed or sinuate. The corolla forms a straight or curved tube. The tube is cylindrical, ventricose or gradually widened towards its apex, \pm equally 5-lobed, spreading or recurved and contorted in bud. The stamens are didynamous and inserted near the base of the corolla tube. The anthers are 2-thecous, oblong or ovoid, \pm spurred at base, and \pm bearded. The disk is short and annular or pulvinate. The ovary is ovoid and consists of 2 locules and has 2 ovules per locule. The style is glabrous or pubescent. The stigma is funnel shaped, bilobed or 2-cleft, and entire or fringed. The fruit is a woody capsule, subglobose at the base and with an elongated beak. Each capsule has 2-4 seeds which are hemispherical, smooth or sculptured and without retinacula (Imlay 1938, Jiaqi et al. 2011, Adhikari et al. 2013).

The pollen of Thunbergeous plants are spheroidal, with the spiraperturate and the exine ornamentation being psilate,

\footnotetext{
Department of Botany, Faculty of Science, Kasetsart University, Bangkok, Thailand.

2 Palynology Special Research Unit, Department of Botany, Faculty of Science, Kasetsart University, Bangkok, Thailand; corresponding author e-mail: fscicps@ku.ac.th.
}

granulate or rarely baculate. This pollen type is very special in this family and has been considered to represent a primitive condition (Lindau 1893, Bremekamp 1955, Raj 1961, Erdtman 1969, Hong-Pin \& Chia-Chi 2005). In Thailand, 13 species were previously reported. Eight species were recorded as T. coccinea, T. erecta, T. fragrans, T. grandiflora, T. hossei, T. laurifolia, T. nivea and T. similis (Imlay 1938). Later, T. papilionacea was reported (Norsaengsri \& Tatana 2012). And then the checklist of Thai plant names was made. Eleven species including native and introduced species were enumerated as T. affinis, T. alata, T. coccinea, T. colpifera, T. erecta, T. fragrans, T. grandiflora, T. hossei, T. laurifolia, T. nivea and T. similis (The Forest Herbarium 2014).

While preparing a treatment of Thunbergia for the Flora of Thailand, the beautiful pink flower of this new species attracted our attention.

\section{Thunbergia impatienoides Suwanph. \& S.Vajrodaya, sp. nov. - Fig. 1-4; Map 1}

Markedly differing from $T$. fragrans Roxb. by having terete stem with 2-furrows (vs 4-angled), terete petiole with a furrow (vs 4-angled), terete pedicel (vs 4-angled), ovate 5-7 nerved bracteoles (vs cordate 10-12 nerved), involute calyx (vs revolute), magenta to pink (vs white), anther theca rounded (vs mucronate theca), stigma magenta to pink (vs white), pollen smaller (42-44 \pm 0.67 vs $54-56 \pm 0.67 \mu \mathrm{m}$ ) and reticulate ornamentation on seed surface (vs glabrous with long papillae ). - Type: C. Suwanphakdee 523 (holo BKF; iso BK, BKF, K, KKU, L, QBG), Thailand, Kanchanaburi, Srisawat, Khao Pu, Salakpra Wildlife Sanctuary Park, 26 Oct. 2016.

Etymology. The specific epithet refers to the gross appearance of its flower which is quite similar to a common ornamental balsam, Impatiens walleriana Hook.f. (Balsaminaceae).

Woody twiner with rootstock, scabrous-strigose in almost all parts. Stems several, slender with runners, terete with 2-furrows. Leaves light green; petiole, $0.7-1.0 \mathrm{~cm}$ long, with a furrow. Lamina elliptic to elliptic-oblong, $4.0-4.5$ by $1.0-2.0 \mathrm{~cm}$, slightly coriaceous, base cordate or slightly hastate, apex acute or mucronate, margin strigose, veins $5-7$, palmate arranged. Flower axillary, solitary; salver-form, $3.0-5.0 \mathrm{~cm}$ diam, magenta to pink with yellow throat; pedicel: $1.5-2.5 \mathrm{~cm}$ long, terete; bracteoles ovate, $1.5-2.0$ by $1.0-1.5 \mathrm{~cm}, 5-7$-nerved, glabrous on adaxial side, base rounded, apex mucronate, margin strigose; calyx: longer than ovary, involute, subequal, 13-toothed, 2.0$4.0 \mathrm{~mm}$ long; corolla tube: slender ventricose, $2.0-3.0 \mathrm{~cm}$ 

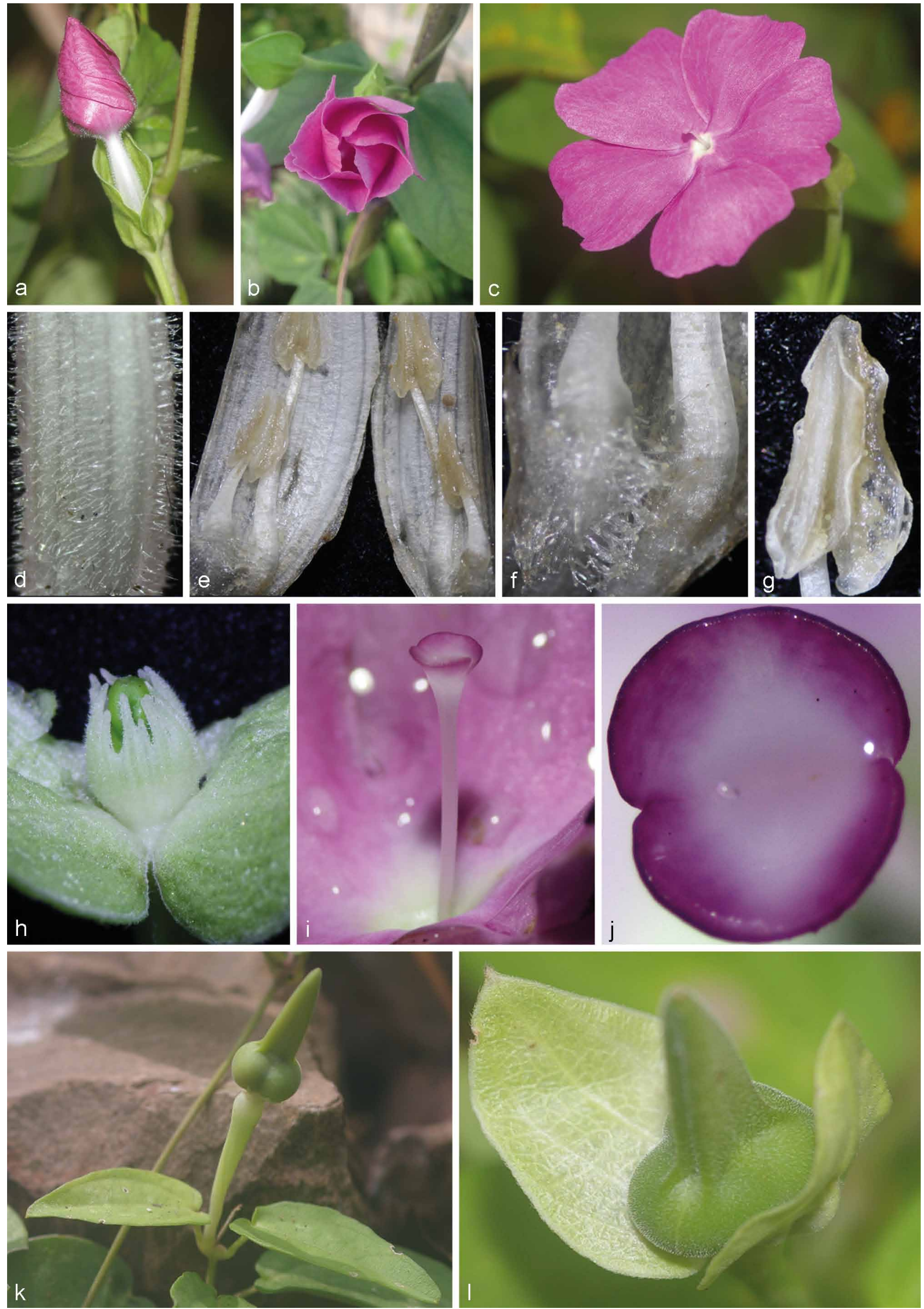

Fig. 1 Thunbergia impatienoides Suwanph. \& S.Vajrodaya. a-b. Flower bud; c. flower; d. corolla tube with glandular hairs; e. stamens; f. glandular hairs on filament base; g. anther; h. calyx and ovary; i. style and stigma; j. stigma; k. fruit; I. fruit close-up (C. Suwanphakdee 523 (BK, BKF, K, KKU, L, QBG)). Photos: C. Suwanphakdee. 


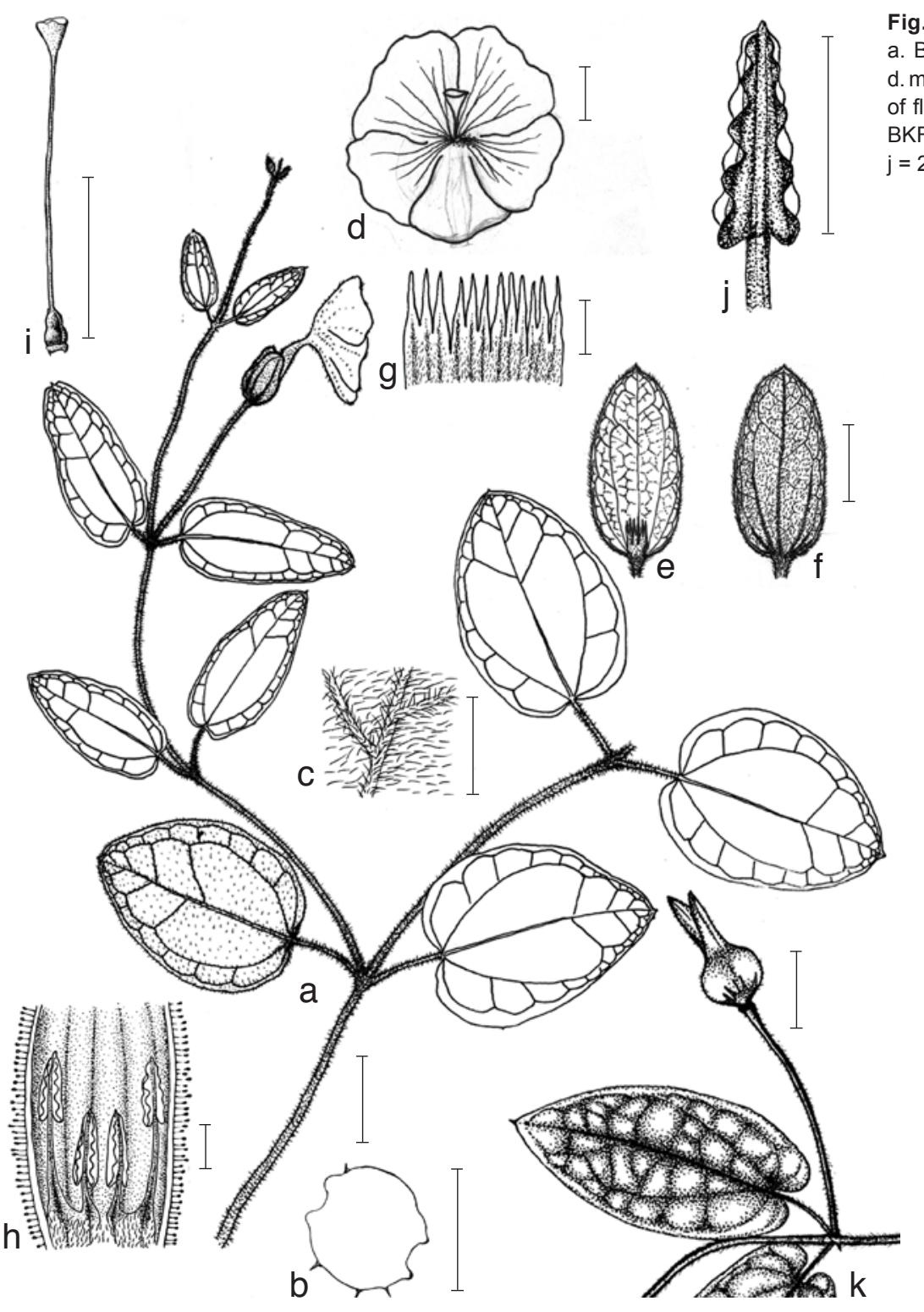

Fig. 2 Thunbergia impatienoides Suwanph. \& S.Vajrodaya a. Branch with flower; b. cross section of stem; c. part of leaf; d. mature flower; e-f. bracteole (inside and outside); g. calyx; h. part of flower; i. pistil; j. anther; k. fruit (C. Suwanphakdee 523 (BK, BKF, K, KKU, L, QBG)). - Scale bars: $a, c-f, i, k=1 \mathrm{~cm} ; b, g, h$, $\mathrm{j}=2 \mathrm{~mm}$. — Drawn by T. Srisuk. long, whitish pale pink, densely glandular hairs outside, glabrous inside; corolla lobe fan-shaped, $2.0-2.5$ by $1.5-2.0$ $\mathrm{cm}$, slightly overlapped, covered with glandular hairs, abaxial surface slightly hirsute, margin repand; stamens erect, densely glandular hairs at the filamentous base, basal theca rounded; shorter stamens filament c. $3 \mathrm{~mm}$ long, anther c. $2 \mathrm{~mm}$ long; longer stamens 2-3: filament c. $6 \mathrm{~mm}$, anther c. $2 \mathrm{~mm}$ long; disk thin and white; pollen grains in monad, spheroidal, 42-44 $\pm 0.67 \mu \mathrm{m}$ diam with spiraperturate aperture. Ovary ovoid with beaked, $2.0-3.0$ by $1.0-2.0 \mathrm{~mm}$ and forming 4-lobed, style $2.0-2.5 \mathrm{~cm}$ long, stigma bilobed, pink or purplish and exsert at anthesis. Fruit a capsule, hirsute, basal part $1.0-1.2$ by $0.7-0.8 \mathrm{~cm}$, beak $1.3-1.5 \mathrm{~cm}$ with pedicel $1.5-2.8 \mathrm{~cm}$ long, thick upward. Seed globose to subglobose, 3.5-4.0 mm diam, seed coat with regular reticulate ornamentation.

Distribution - Endemic to Thailand (border of northern and western Thailand in Tak province and in western Thailand in Kanchanaburi and Ratchaburi provinces).

Habitat \& Ecology — In shaded area in dipterocarp and mixed deciduous forests. Flowering: November to January; fruiting: December to February.

Specimens examined. Tak, 18 Jan. 1974, C. Phengklai 3156 (BKF); Ratchaburi, Pho Tharam, Khao Tha Kho, 21 Nov. 1985, G. Staples 318 (BKF); Kanchanaburi, Srisawat, Khao Phu, Salakpra wildlife sanctuary, 26 Oct. 2015, C. Suwanphakdee 523 (type).
Notes - Based on gross morphological characters Thunbergia impatienoides is similar to $T$. fragrans but differ in having runner stems which is unique. The stem is terete with two furrows (one on each side) and the petiole has a furrow. The flower, which is very showy, is always presented as solitary in the leaf axil. It has an attractive and for Asian Thunbergia unseen pink colour. The distinguishing flower colour characters are dark purple or magenta in flowering bud and turning to pink when mature. The pedicel is rounded and scabrous. The flower is salver-shaped when mature. The corolla lobe is fan-shaped. The five stamens are uniformly didynamous with two shorter and three longer ones. The base of the theca is rounded (usually spurred in Thunbergioideae). The capsule is hirsute and not glabrous and waxy as in T. fragrans (compared in Table 1). The seed of both species are similar but the surface is reticulate in $T$. impatienoides and long papillate in T. fragrans (Fig. 3). The pollen grains are spheroidal monads. The aperture is spiraperturate which is the common character of Thunbergia. The pollen ornamentation is baculate with fossula. The difference of pollen morphology between $T$. impatienoides and related species is the size $(42-44 \pm 0.67 \mu \mathrm{m}$ vs $54-56 \pm$ $0.68 \mu \mathrm{m}$ ) which significantly supports $T$. impatienoides to be new to science. The pollen morphological characters of both species are shown (Fig. 4). 


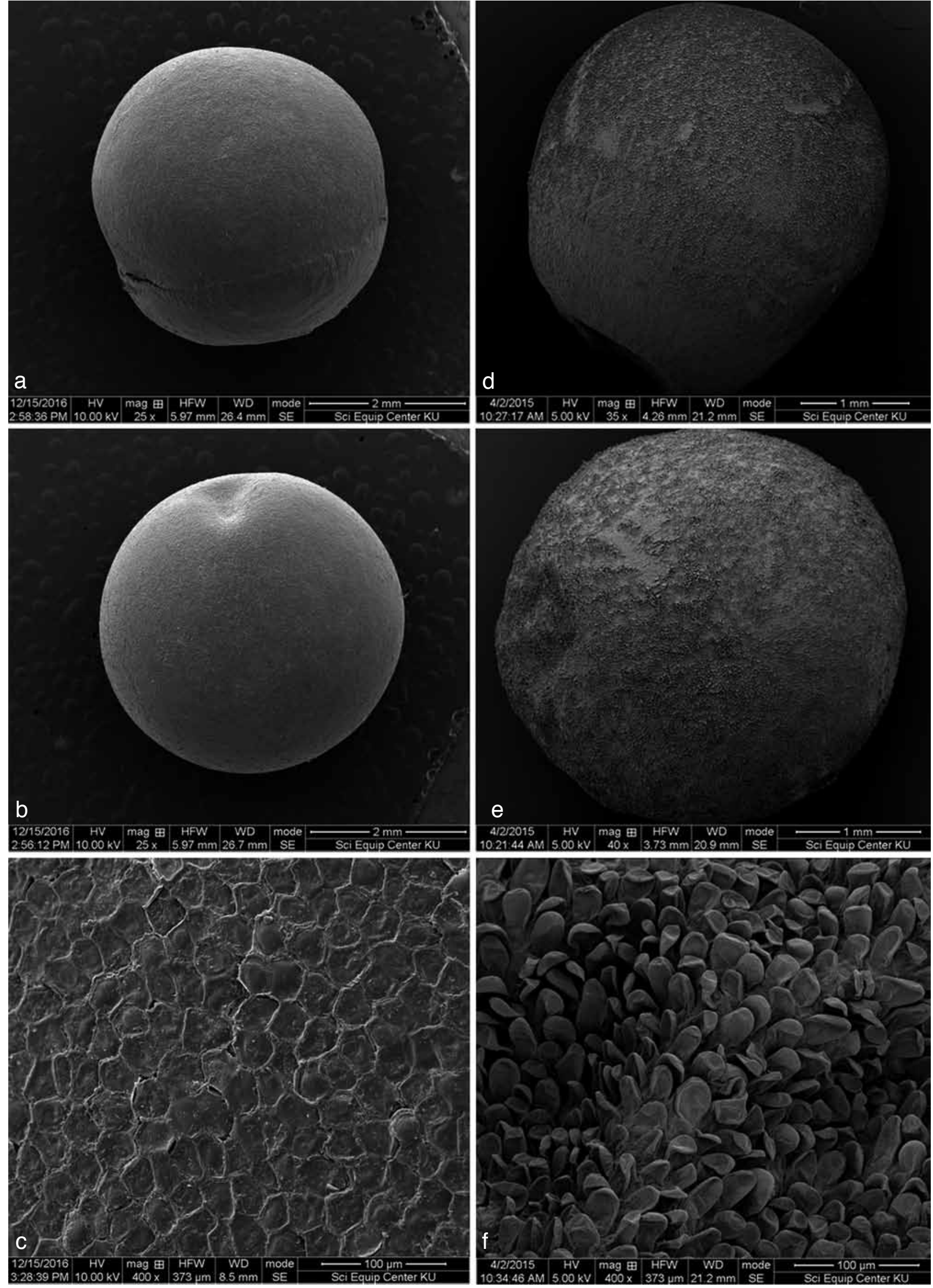

Fig. 3 Seed morphology of a-c: Thunbergia impatienoides Suwanph. \& S.Vajrodaya. a, b. Seed (size and top views); c. reticulate ornamentation on seed surface . - d-f: Thunbergia fragrans Roxb. d, e. Seed (size and top views); f. long papillae on seed surface (a-c: C. Suwanphakdee 523 (BK, BKF, K, KKU, L, QBG); d-f: C. Suwanphakdee 511 (BK, BKF, KKU, QBG)). 

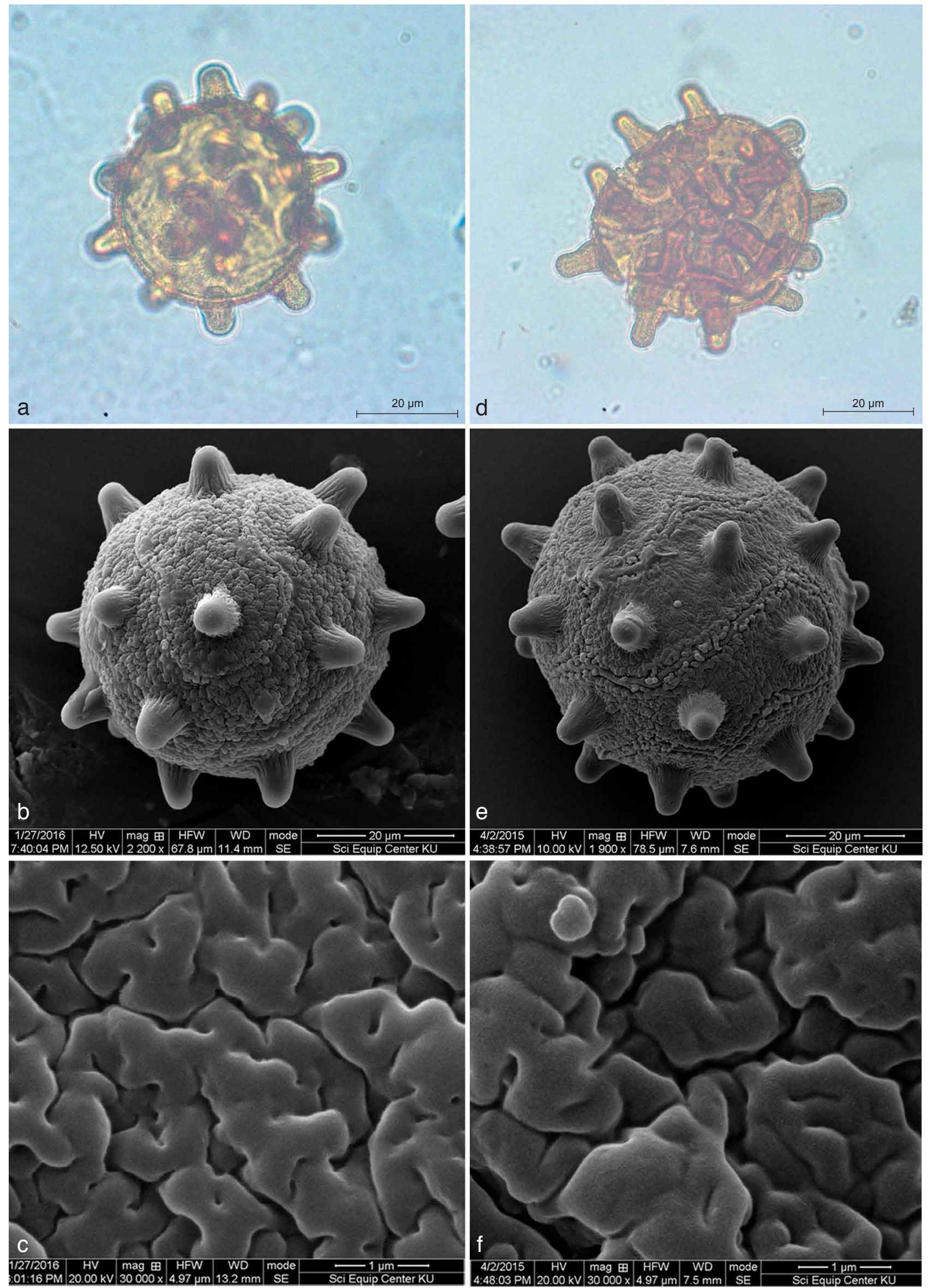

Fig. 4 Pollen morphology. a-c: Thunbergia impatienoides Suwanph. \& S.Vajrodaya. a. Pollen from light microscope; b. pollen from SEM; c. fossula. — d-f: Thunbergia fragrans Roxb. d. Pollen from light microscope; e. pollen from SEM; f. fossula (a-c: C. Suwanphakdee 523 (BK, BKF, K, KKU, L, QBG); d-f: C. Suwanphakdee 511 (BK, BKF, KKU, QBG)). 
Table 1 Comparison between Thunbergia fragrans and T. impatienoides.

\begin{tabular}{|c|c|c|}
\hline Character & T. fragrans & T. impatienoides \\
\hline Stem & 4-angled or forming 4-winged, hirsute & terete with 2 furrows, scabrous and strigose \\
\hline Petiole & 4-angled, hirsute & terete with a furrow, scabrous and strigose \\
\hline Leaf & scabrous with short and long hairs & scabrous and strigose \\
\hline Pedicel & $1.5-2.5 \mathrm{~cm}$ long, 4-angled or slightly 4-winged, glabrescent & $3.5-4.0 \mathrm{~cm}$ long, rounded, scabrous \\
\hline Flower & solitary, paired up to 4 or fascicled, white & always solitary, magenta to pink \\
\hline Bracteoles & $\begin{array}{l}0.8-1.2 \text { by } 1.5-1.8 \mathrm{~cm} \text {, cordate with } 10-12 \text {-nerved, } \\
\text { glabrescent on abaxial }\end{array}$ & $\begin{array}{l}1.0-1.5 \text { by } 1.5-2.0 \mathrm{~cm} \text {, ovate with } 5-7 \text {-nerved, scabrous and strigose } \\
\text { on abaxial }\end{array}$ \\
\hline Calyx & $\begin{array}{l}\text { much longer than ovary, } 11-14 \text {-toothed and revolute, } \\
4.0-5.0 \mathrm{~mm} \text { long, scabrous }\end{array}$ & $\begin{array}{l}\text { subequal or shorter than ovary, 13-toothed and involute, } \\
2.0-4.0 \mathrm{~mm} \text { long, scabrous }\end{array}$ \\
\hline Corolla tube & $2.0-4.0 \mathrm{~cm}$ long, white, sparsely glandular hairs or glabrescent & $2.0-3.0 \mathrm{~cm}$ long, whitish pale pink, densely glandular, hairs \\
\hline Corolla lobe & obovate & fan-shaped \\
\hline Stamen & sparely glandular hair or glabrescent & densely glandular hairs \\
\hline Filament & didynamous, slightly glandular hairs at the base & $\begin{array}{l}\text { didynamous or } 5 \text { with } 2 \text { short and } 3 \text { long, densely glandular hairs } \\
\text { at the base }\end{array}$ \\
\hline Pollen & $54-56 \pm 0.68 \mu \mathrm{m}$ & $42-44 \pm 0.67 \mu \mathrm{m}$ \\
\hline Stigma & white & pink or purplish \\
\hline Fruit & glabrous & hirsute \\
\hline Seed & glabrous with long papillae & reticulate ornamentation \\
\hline
\end{tabular}

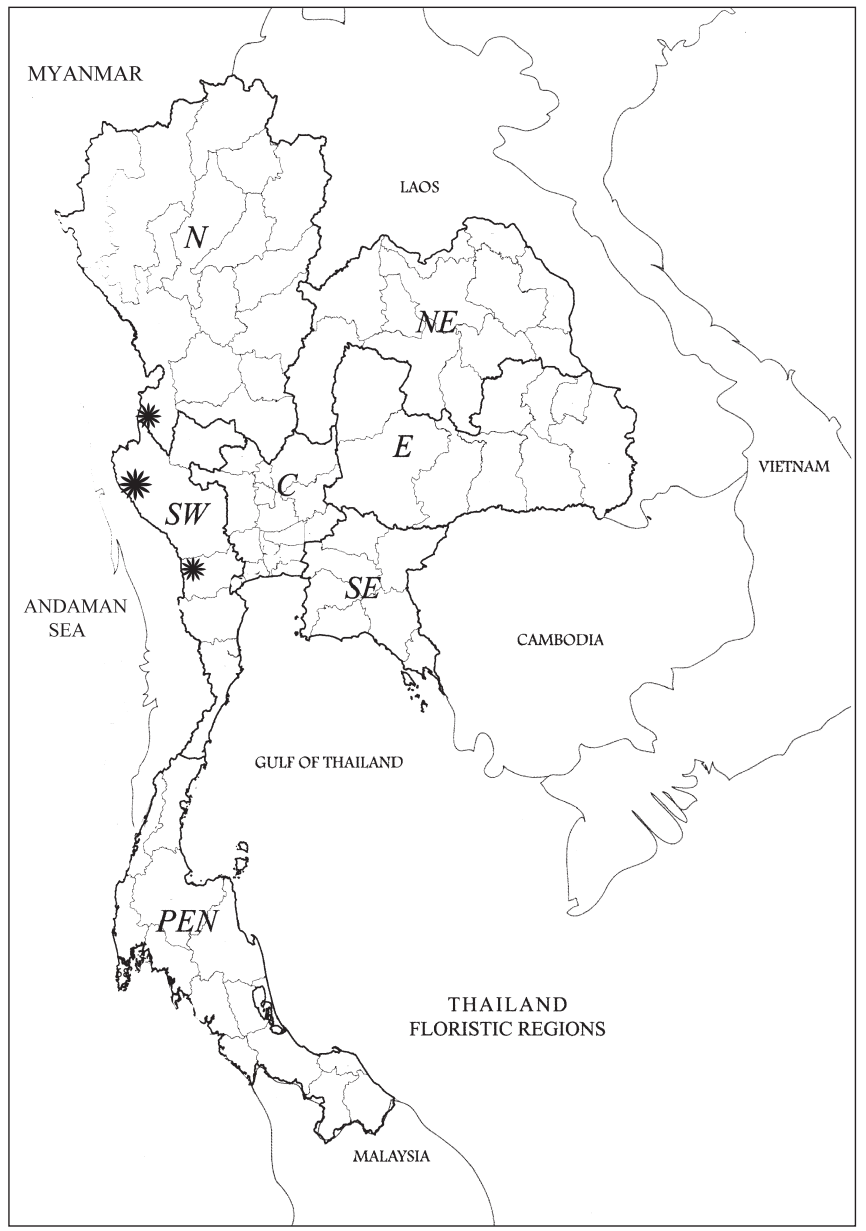

Map 1 Distribution of Thunbergia impatienoides Suwanph. \& S.Vajrodaya.
Acknowledgements We thank the directors, curators and staff of herbaria (AAU, BK, BKF, BM, BO, C, G, G-DC, K, K-W, KEP, KKU, L, QBG, SING, $T C D$ ) for permission to study the specimens and references. We would like to thank Mr. Teerawut Srisuk for the line drawings and Dr. Piyakaset Suksathan (QBG) and Prof. Dr. Henrik Balslev (AAU) for useful comments. This work was supported by Thailand Research Fund (TRF) no. TRG5780290 and Research and Development Kasetsart University Institute, Kasetsart University.

\section{REFERENCES}

Adhikari B, Pendry CA, Watson MF, et al. 2013. An account of Thunbergia (Acanthaceae) in Nepal, with a description of the new species T. nepalensis. Kew Bulletin 68: 651-661.

Borg JA, McDade AL, Schönenberger J. 2008. Molecular phylogenetics and morphological evolution of Thunbergioideae (Acanthaceae). Taxon 57 (3): 811-822.

Bremekamp CEB. 1953. The delimitation of the Acanthaceae. Proceedings of the Koninklijke Nederlandse Akademie van Wetenschappen: Series C: Biological and Medical Sciences 56: 533-546.

Bremekamp CEB. 1955. The Thunbergia species of the Malesian area. Verhandelingen der Koninklijke Nederlandsche Akademie van Wetenschappen. Afdeeling Natuurkunde, Sectie 2, 2 : 50 (4): 1-90.

Brummitt RK. 1989. Against separating Mendonciaceae from Acanthaceae. Acanthus 5: 1-3.

Erdtman G. 1969. Handbook of palynology. Copenhagen, Denmark.

Hong-Pin T, Chia-Chih. 2005. Pollen morphology of six species in Thunbergia, of one species each in Staurogyne and Acanthus (Acanthaceae) from China. Acta Phytotaxonomica Sinica 43 (2): 116-122.

Imlay BJ. 1938. The taxonomy of the Siamese Acanthaceae. PhD thesis, The University of Aberdeen, Scotland.

Jiaqi SQ, Yunfei D, Daniel TF. 2011. Thunbergia. In: DengY, Jia-qi H, Daniel TF, et al. (eds), Flora of China, Vol. 19: 377-379.

Lindau G. 1893. Übersicht über die bisher bekannten Arten der Gattung Thunbergia L.f. Botanische Jahrbücher für Systematik, Pflanzengeschichte und Pflanzengeographie 41: 31-41.

Lindau G. 1895. Acanthaceae. In: Engler A, Prantl K (eds), Die natürlichen Pflanzenfamilien, vol. 3b: 274-354. Engelmann, Leipzig.

Norsaengsri M, Tatana N. 2012. Plants in Doi Nang Non. Queen Sirikit Botanic Garden, Chiang Mai [in Thai].

Raj B. 1961. Pollen morphological studies in the Acanthaceae. Grana Palynologica 3: 3-108.

Schönenberger J, Endress PK. 1998. Structure and development of the flowers in Mendoncia, Pseudocalyx, and Thunbergia (Acanthaceae) and their systematic implications. International Journal of Plant Science 159: 446-465.

Takhtajan A. 1997. Diversity and classification of flowering plants. Columbia University Press, New York.

The Forest Herbarium, Royal Forest Department. 2014. Thai Plant Names, Tem Smitinand, Revised Edition. Prachachon Co. Ltd, Bangkok. 